\title{
KEANEKARAGAMAN SPESIES BURUNG DI HUTAN MANGROVE PULAU KELAGIAN BESAR PROVINSI LAMPUNG
}

\author{
(Diversity Of Bird Species In Mangrove Forest Kelagian Besar Island Of Lampung \\ Province)
}

\author{
Memo Dinda Nugraha*, Agus Setiawan, Dian Iswandaru, Yulia Rahma Fitriana \\ Jurusan Kehutanan, Fakultas Pertanian Universitas Lampung \\ ${ }^{*}$ Email : memodindan@gmail.com
}

Diterima : 01/07/2020, Direvisi : 08/11/2020, Diterbitkan 01/03/2021

\begin{abstract}
The existence of mangrove forests is very important in an area because as a habitat for various types of wildlife, especially birds. This study aims to determine the diversity of bird species in the Kelagian Besar Mangrove Forest, Lampung Province. Data on bird species diversity was obtained by the IPA (Indices Ponctual Abundance) method. Data collection of bird species by recording the type and number of individual birds found. Species identification also uses the method of bird recognition directly by people who know the birds in the area such as the local community or an expert on birds. Data obtained in the field are then analyzed using the Shanon-Winner diversity index formula. The results found 27 species of birds from 21 families with a total of 741 individual birds in the Kelagian Besar Mangrove Forest. While the diversity index value is 2.26 with medium index criteria. There are 8 protected bird species, namely the black-necked darautaut (Sterna sumatrana), the white-wing daralaut (Chlidonias leucopterus), the oyster daralaut (Gelochelidon nilotica), the white belly eagle (Haliaeetus leucogaste), the brontok eagle (Spizaetus cirrhatus), oyster belly Rhipidura javanica), sabine seagulls (Xema sabini), and large fissures (Fregata minor)..
\end{abstract}

Keywords; diversity; bird; Forest; mangrove

\begin{abstract}
ABSTRAK
Keberadaan hutan mangrove sangat penting dalam suatu wilayah karena sebagai habitat berbagai jenis satwa liar terutama burung. Penelitian ini bertujuan mengetahui keanekaragaman spesies burung di Hutan Mangrove Pulau Kelagian Besar, Provinsi Lampung. Data mengenai keanekaragaman spesies burung diperoleh dengan metode IPA (Indices Ponctual Abundance. Data yang telah diperoleh di lapangan, kemudian dianalisis dengan menggunakan rumus indeks keanekaragman Shanon-Winner. Hasil penelitian ditemukan sebanyak 27 spesies burung dari 21 famili dengan total individu sebanyak 741 ekor. Sedangkan nilai indeks keanekaragamannya yaitu 2.26 dengan kriteria indeks sedang. Terdapat 8 spesies burung yang dilindungi yaitu daralaut tengkuk-hitam (Sterna sumatrana), daralaut sayap-putih (Chlidonias leucopterus), daralaut tiram (Gelochelidon nilotica), elanglaut perut putih (Haliaeetus leucogaste), elang brontok (Spizaetus cirrhatus), kipasan belang (Rhipidura javanica), camar sabine (Xema sabini), dan cikalang besar (Fregata minor).
\end{abstract}

Kata kunci; keanekaragaman; burung; hutan; mangrove 


\section{PENDAHULUAN}

Burung merupakan salah satu komponen ekosistem yang memiliki peran penting yang mendukung berlangsungnya siklus suatu kehidupan organisme (Watalee et al., 2013). Hal ini terkait dengan peran burung dalam lingkungan ekologi sebagai prey (mangsa), predator (pemangsa), pollinator (penyerbukan bunga), dan penyebar biji (Setia, 2008). Oleh karena itu, keberadaan burung dapat menjadi penting dalam ekosistem hutan mangrove karena keanekaragaman spesies burung menggambarkan kestabilan sebuah ekosistem, semakin baik keanekaragaman spesies maka semakin stabil ekosistem tersebut (Sajria et al, 2019).

Mangrove adalah vegetasi hutan yang dipengaruhi oleh pasang surut air laut yang memiliki fungsi ganda dan merupakan mata rantai yang sangat penting dalam memelihara keseimbangan siklus biologi di suatu perairan (Patang, 2012). Hutan mangrove termasuk salah satu ekosistem yang langka di Dunia, luasnya hanya $2 \%$ dari luas permukaan bumi dan ekosistem mangrove terluas terdapat di Indonesia. Menurut (Majid et al., 2016), hutan mangrove di Indonesia saat ini sudah dalam keadaan kritis, sekitar 5,9 juta hektar (68\%) dari luas keseluruhan 8,6 juta hektar mengalami kerusakan, kondisi ini akan berdampak pada keberlangsungan hidup satwa-satwa terutama burung. Selain itu, hutan mangrove merupakan sumber hara dan habitat dari berbagai jenis burung liar (Sari et al., 2019). Beberapa jenis burung memanfaatkan vegetasi mangrove sebagai tempat istirahat, tidur dan bersarang. Vegetasi mangrove juga dimanfaatkan oleh beberapa jenis burung sebagai lokasi antara (stop over area) dan tempat mencari makan, karena ekosistem mangrove merupakan ekosistem yang kaya (Iswandaru et al., 2018).

Keberadaan hutan mangrove sangat penting dalam suatu wilayah karena berperan sebagai tempat mencari makan (feeding ground), tempat memijah (spawning ground), dan tempat berkembang biak (nursery ground) berbagai jenis ikan, udang, kerang dan biota laut lainnya, serta tempat bersarang berbagai jenis satwa liar terutama burung (Heru, 2013). Keberadaan jenis burung pada habitat hutan mangrove sangat dipengaruhi oleh faktor lingkungan baik faktor biotik maupun abiotik dari hutan mangrove yang ditempatinya tersebut (Abdullah, 2013).

Pulau Kelagian Besar merupakan salah satu dari beberapa pulau yang jauh dari pemukiman penduduk dan memiliki hutan mangrove di pesisir pantainya, sehingga berpotensi menjadi habitat burung liar. Namun, inventarisasi maupun monitoring spesies burung dan peran ekologinya belum pernah dilakukan sehingga penelitian ini penting dilakukan. Penelitian ini bertujuan untuk mengetahui keanekaragaman spesies burung dan status konservasinya serta memberikan gambaran mengenai tingkat kestabilan ekosistem hutan mangrove di Pulau Kelagian Besar.

\section{METODE}

Penelitian dilakukan selama bulan Agustus 2019. Lokasi pengumpulan data terletak di Hutan Mangrove Pulau Kelagian Besar Kabupaten Pesawaran, Provinsi Lampung. Pulau Kelagian Besar merupakan salah satu dari 37 pulau yang terdapat di Kabupten Pesawaran yang tidak berpenghuni. Secara administratif, Pulau Kelagian Besar terletak di Desa Gebang, Kecamatan Padang Cermin, Kabupaten Pesawaran, Provinsi Lampung dan secara geografis terletak pada koordinat $5^{\circ} 37^{\prime} 44.41^{\prime \prime}$ Lintang Selatan (LS) dan 105'13'29.59" Bujur Timur (BT). Akses menuju pulau dapat ditempuh menggunakan speed boat selama 15 menit atau kapal kayu selama 20 menit dari 
dermaga Ketapang Kecamatan Padang Cermin. Berdasarkan data dari Badan Informasi Geospasial (2011), Pulau Kelagian memiliki luas sebesar 424.56 hektar, sedangkan luas hutan mangrovenya sebesar 41.6440 hektar. Kondisi ekosistem di Pulau Kelagian Besar masih alami dan dalam kondisi baik, dari hasil pengamatan di lapangan belum ditemukan eklpoitasi dan alih fungsi lahan. Pulau ini merupakan salah satu pulau tidak berpenghuni serta jauh dari pemukiman penduduk, masyarakat disekitarnya memanfaatkan pulau hanya sebagai lokasi wisata.

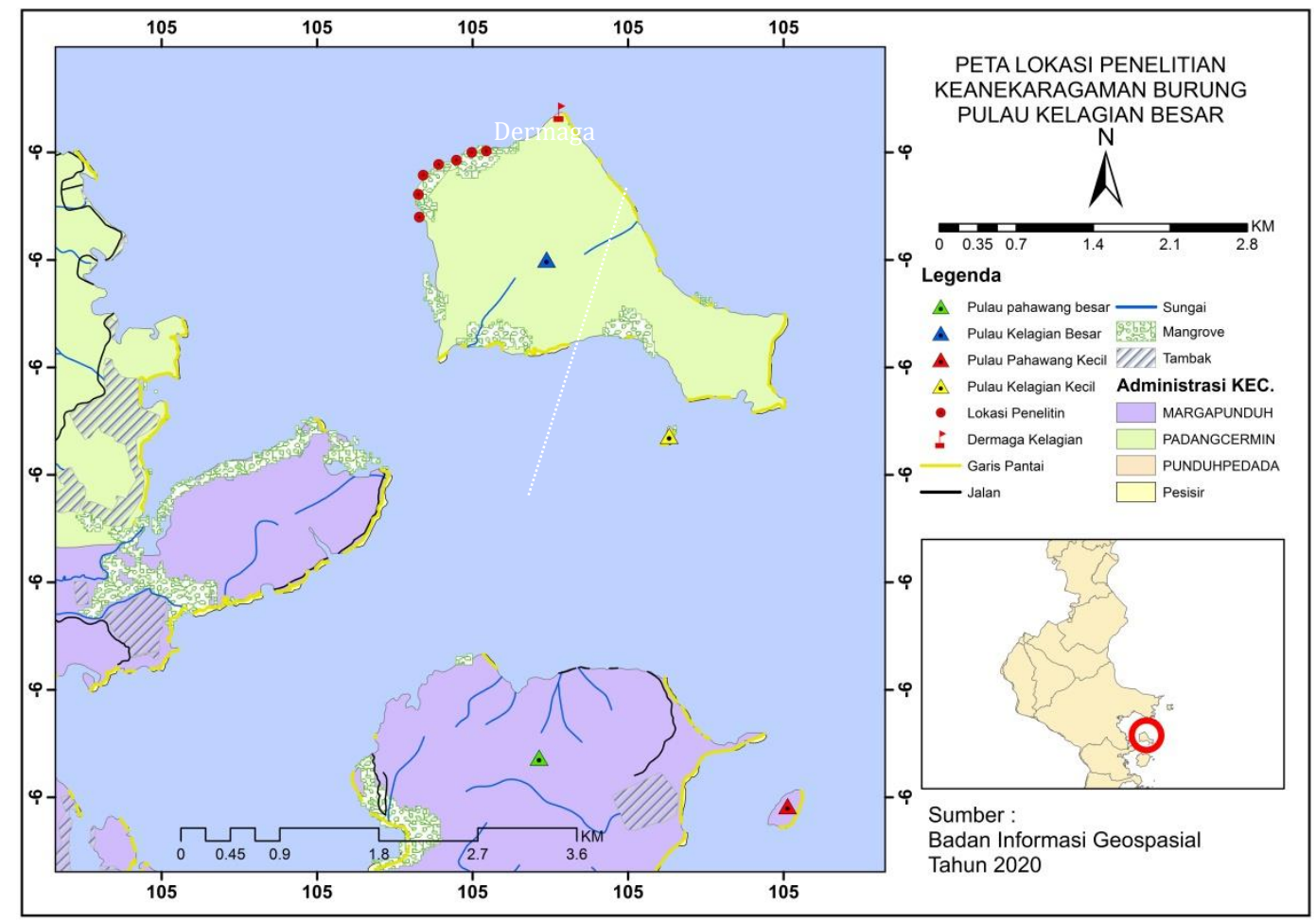

Gambar 1. Peta lokasi penelitian.

Figure 1. Map of the research location.

Alat yang digunakan dalam penelitian ini adalah kamera digital Nikon D5300 lensa sigma 70-300 mm macro ultrasonic, teropong binokuler, stopwatch, alat tulis dan lembar pengamatan. Sementara bahan yang menjadi objek penelitian adalah berbagai jenis burung yang ditemukan.

Data mengenai keanekaragaman spesies burung diperoleh dengan metode IPA (Indices Ponctual Abundance).. Pada penelitian ini terdapat 7 titik pengamatan dengan jarak setiap titik yaitu $200 \mathrm{~m}$. Pengamatan dilakukan pada pagi hari pukul 06.00-09.00 WIB dan pada sore hari pukul 16.00-18.00 WIB. Pemilihan waktu ini dilakukan karena pada pagi dan sore hari burung sedang aktif melakukan kegiatan, sehingga lebih mudah untuk menjumpai burung (Sari et al, 2019).

Pada setiap titik, dilakukan pengamatan selama 20 menit untuk mencatat jenis dan jumlah spesies burung pada radius/ jarak pandang $50 \mathrm{~m}$. Identifikasi spesies dilakukan menggunakan buku panduan lapangan burung (MacKinnon et al., 2010), sedangkan penulisan tata nama berdasarkan Sukmantoro et al.,(2007). Dokumentasi atau pengambilan foto untuk identifikasi spesies burung yang teramati secara detail (Jhenkhar et al., 2016: Iswandaru et al., 2018). Data yang diperoleh di lapangan, 
kemudian dianalisis dengan menggunakan rumus indeks keanekaragman ShanonWienner (Magurran, 2004) yaitu:

$$
H^{\prime}=-\Sigma \text { pi In pi }
$$

Dengan pi $=\frac{\sum \text { burungspesieske- } i}{\Sigma \text { total burung }}$

Dimana :

$\mathrm{H}^{\prime}=$ Indeks keanekaragaman jenis

$\mathrm{Pi}=$ Proporsi individu suatu spesies terhadap keseluruhan individu yang dijumpai

In = Logaritma natural

Kriteria nilai indeks keanekaragaman (Magurran, 2004) sebagai berikut.

$H^{\prime} \leq 1$ : keanekaragaman rendah

$1<\mathrm{H}^{\prime}<3$ : Keanekaragaman sedang

$\mathrm{H}^{\prime} \geq 3 \quad$ : Keanekaragaman tinggi

\section{HASIL DAN PEMBAHASAN}

Hasil inventarisasi di Hutan Mangrove Pulau Kelagian Besar, ditemukan sebanyak 27 spesies burung dari 21 famili dengan jumlah 741 individu. Burung-burung yang ditemukan yaitu dalam keadaan sedang bermain, mencari makan, bertengger, dan terbang di berbagai jenis pohon. Sama halnya dengan penelitian Latupapua (2016) mengungkapkan bahwa suatu vegetasi mangrove dapat dimanfaatkan oleh burung untuk melakukan aktivitasnya seperti makan, bermain, bertengger, dan membuat sarang. Adapun jenis dan jumlah individu masing-masing spesies pada setiap lokasi pengamatan dapat dilihat dalam Tabel 1.

Selanjutnya, indeks keanekaragaman menunjukkan kondisi dari ekosistem, semakin baik indeks keanekaragaman spesies maka suatu ekosistem akan semakin stabil (Sajria et al., 2019). Kestabilan ekosistem menunjukkan produktivitas hutan tersebut tergolong cukup baik, tekanan terhadap ekologis hutan termasuk sedang dan kondisi ekosistem cukup seimbang, sehingga dapat menunjang kelestarian habitat burung (Mardiyanti et al., 2013). Hasil perhitungan menggunakan rumus ShannonWienner, keanekaragaman spesies burung di Hutan Mangrove Pulau Kelagian Besar termasuk dalam kategori sedang $(1<2.265<3)$. Nilai indeks keanekaragaman yang ditunjukkan oleh gambar 2 memperlihatkan nilai indeks keanekaragaman di setiap titik pengamatan yang berbeda. Dari berbagai spesies yang berhasil diidentifikasi, diketahui bahwa keanekaragaman spesies dari setiap titik pengamatan tersebut menunjukkan hasil yang beragam, berikut perbedaan nilai indeks keanekaragaman di tujuh (7) lokasi pengamatan (Gambar 2). 


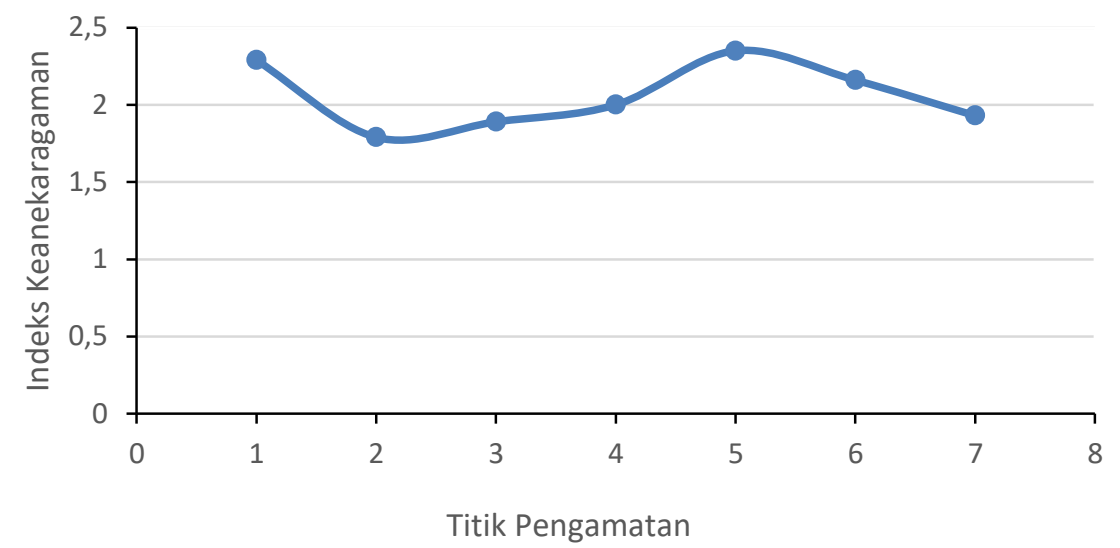

Gambar 2. Grafik perbandingan keanekaragaman masing-masing titik pengamatan.

Figure 2. Comparison chart of the diversity of each observation point.

Dari grafik diatas, diketahui bahwa keanekaragaman tertinggi terdapat pada titik pengamatan 5 (lima) dengan nilai keanekaragaman sebesar 2.35. Sedangkan nilai indeks keanekaragaman yang paling rendah berada di titik pengamatan 2 (dua) dengan nilai indeks 1.79. Perbedaan tersebut dapat disebabkan oleh kondisi ekologi yang berbeda terutama variasi jenis tumbuhan serta tinggi rendahnya populasi burung itu sendiri (Lekipiou dan Nanlohy 2018). Semakin bervariasi vegetasi di suatu ekosistem maka keanekaragaman burung cenderung semakin tinggi (Fikriyanti et al., 2018). Selain itu, faktor lainnya adalah kondisi hutan mangrove yang masih alami dan rapat. Pada titik pengamatan ini juga terdapat hewan lain seperti ubur-ubur dan ikanikan kecil yang tidak ditemukan pada titik lainnya. Hal ini disebabkan karena pada titik pengamatan 5 terdapat lumpur dan genangan air yang dapat menjadi tempat mencari makan berbagai jenis burung (feeding ground). Menurut Mubarrok dan Ambarwati (2019), tingginya keanekaragaman burung disebabkan oleh tersedianya sumber pakan dan terdapat banyak vegetasi yang dominan di suatu habitat. Sama halnya dengan penelitian Kristianti et al. (2017), keanekaragaman burung mudah dijumpai pada lokasi yang memiliki kelimpahan jenis pakan yang mampu memenuhi kebutuhan hidupnya. Penelitian Paramita et al. (2015) menyatakan bahwa vegetasi di kawasan hutan mangrove dapat dijadikan populasi burung sebagai tempat beristirahat dan bersarang. Sebaliknya, nilai indeks terendah pada titik pengamatan 2 dapat disebabkan oleh faktor kondisi vegetasi yang kurang rapat dan jenis tumbuhan yang kurang bervariasi. Hal yang sama juga diungkapkan oleh (Supriyanto et al., 2014), suatu komunitas dikatakan memiliki keanekaragaman yang rendah jika komunitas itu disusun oleh sedikit spesies dan hanya sedikit saja spesies yang dominan.

Secara umum, kondisi hutan mangrove di Pulau Kelagian Besar masih cukup rapat dan masih alami menyebabkan burung-burung merasa terlindungi dan memudahkan mereka untuk menemukan sumber pakan seperti ikan. Menurut (Julyanto et al., 2016), ketersediaan pakan alami seperti ikan sangat mempengaruhi keberadaan burung air karena ikan menjadi daya tarik bagi burung-burung air untuk datang setiap tahunnya. Ketersediaan sumber pakan tersebut dapat menjadi faktor utama keanekaragaman jenis burung di suatu daerah. Seperti yang dinyatakan oleh (Fikriyanti et al., 2018), ketersedian pakan pada hutan mangrove berbeda dengan ketersedian pakan di hutan dataran rendah, karena ketersediaan pakan di hutan mangrove lebih beragam. Selain ketersediaan pakan, menurut (Firdaus et al., 2014). perbedaan keanekaragaman burung di beberapa lokasi juga dapat disebabkan oleh musim dan kemampuan peneliti. 
Jurnal Belantara Vol. 4, No. 1, Maret 2021 (56-65)

Tabel 1. Keanekaragaman spesies burung di Hutan Mangrove Pulau Kelagian Besar

Table 1. Diversity of bird species in Kelagian Besar Island Mangrove Forest

\begin{tabular}{|c|c|c|c|c|c|c|}
\hline \multirow{2}{*}{ No } & \multirow{2}{*}{ Family } & \multirow{2}{*}{ Jenis burung } & \multirow{2}{*}{ Nama IImiah } & \multicolumn{3}{|c|}{ Status Konservasi } \\
\hline & & & & UU RI & IUCN & CITES \\
\hline 1 & Alcedinidae & Cekakak sungai & Halcyon chloris Boddaert, 1783 & TD & $\mathrm{LC}$ & - \\
\hline 2 & & Cekakak belukar & Halcyon smyrnensis (Linnaeus, 1758) & TD & LC & - \\
\hline 3 & & Cekakak suci & $\begin{array}{l}\text { Halcyon sancta Vigors \& Horsfield, } \\
1827\end{array}$ & TD & LC & - \\
\hline 4 & & Rajaudang biru & Alcedo coerulescens Vieillot, 1818 & TD & LC & - \\
\hline 5 & Sternidae & $\begin{array}{l}\text { Daralaut Tengkuk- } \\
\text { hitam }\end{array}$ & Sterna sumatrana Raffles, 1822 & $\mathrm{D}$ & LC & - \\
\hline 6 & & $\begin{array}{l}\text { Daralaut Sayap- } \\
\text { putih }\end{array}$ & $\begin{array}{l}\text { Chlidonias leucopterus (Temminck, } \\
\text { 1815) }\end{array}$ & $\mathrm{D}$ & LC & - \\
\hline 7 & & Dara laut tiram & Gelochelidon nilotica (Gmelin, 1789) & $\mathrm{D}$ & LC & - \\
\hline 8 & Accipitridae & $\begin{array}{l}\text { Elanglaut perut } \\
\text { putih }\end{array}$ & Haliaeetus leucogaste (Gmelin, 1788) & $\mathrm{D}$ & LC & II \\
\hline 9 & & Elang brontok & Spizaetus cirrhatus (Gmelin, 1788) & $\mathrm{D}$ & LC & II \\
\hline 10 & Apodidae & Walet linci & $\begin{array}{l}\text { Collocalia linchi (Horsfield \& F. Moore, } \\
\text { 1854) }\end{array}$ & TD & LC & - \\
\hline 11 & Rhipiduridae & Kipasan belang & Rhipidura javanica (Sparrman, 1788) & $\mathrm{D}$ & LC & - \\
\hline 12 & Dicaeidae & Cabai polos & Dicaeum concolor Jerdon, 1840 & TD & LC & - \\
\hline 13 & Meropidae & Kirikkirik laut & Merops philippinus Linnaeus, 1766 & TD & LC & - \\
\hline 14 & Nectariniidae & $\begin{array}{l}\text { Burungmadu } \\
\text { sriganti }\end{array}$ & Cinnyris jugularis (Linnaeus, 1766) & TD & LC & - \\
\hline 15 & Cisticolidae & Cinenen kelabu & Orthotomus ruficeps (Lesson, 1830) & TD & LC & - \\
\hline
\end{tabular}




\begin{tabular}{|c|c|c|c|c|c|c|}
\hline 16 & $\begin{array}{l}\text { Pycnonotida } \\
\text { e }\end{array}$ & Cucak kutilang & $\begin{array}{l}\text { Pycnonotus aurigaster (Jardine \& } \\
\text { Selby, 1837) }\end{array}$ & TD & LC & - \\
\hline 17 & Laniidae & Bentet kelabu & Lanius schach Linnaeus, 1758 & TD & LC & - \\
\hline 18 & Picidae & Caladi tilik & $\begin{array}{l}\text { Dendrocopos moluccensis Gmelin, } \\
1788\end{array}$ & TD & LC & - \\
\hline 19 & Cuculidae & Kedasi hitam & Surniculus Iugubris (Horsfield, 1821) & TD & LC & - \\
\hline 20 & $\begin{array}{l}\text { Scolopacida } \\
\text { e }\end{array}$ & Trinil pantai & Actitis hypoleucos (Linnaeus, 1758) & TD & LC & - \\
\hline 21 & $\begin{array}{l}\text { Pachycephal } \\
\text { idae }\end{array}$ & Kancilan bakau & Pachycephala grisola (Blyth, 1843) & TD & LC & - \\
\hline 22 & Laridae & Camar sabine & Xema sabini (J. Sabine, 1819) & $\mathrm{D}$ & LC & - \\
\hline 23 & Columbidae & Punai gading & Treron vernans (Linnaeus, 1771) & TD & LC & - \\
\hline 24 & Halcyonidae & Pekaka emas & $\begin{array}{l}\text { Pelargopsis capensis (Linnaeus, } \\
\text { 1766) }\end{array}$ & TD & LC & - \\
\hline 25 & Fregatidae & Cikalang besar & Fregata minor (J. F. Gmelin, 1789) & $\mathrm{D}$ & LC & - \\
\hline 26 & $\begin{array}{l}\text { Hemiprocnid } \\
\text { ae }\end{array}$ & Tepekong jambul & $\begin{array}{l}\text { Hemiprocne longipennis Rafinesque, } \\
1802\end{array}$ & TD & LC & - \\
\hline 27 & Cisticolidae & Perenjak jawa & Prinia familiaris Horsfield, 1821 & TD & LC & - \\
\hline
\end{tabular}

\section{Keterangan :}

D/TD = Dilindungi/Tidak Dilindungi menurut Peraturan Menteri LHK No. 106/ 2018, LC= Least Concern/Risiko Rendah (status konservasi IUCN Red list versi 3.1), II= CITES Apendiks II. 
Spesies burung yang paling banyak ditemui di Hutan Mangrove Pulau Kelagian Besar adalah walet linci (Collocalia linchi) sebanyak 295 individu. Walet linchi (Collocalia linchi) merupakan burung yang sangat umum dijumpai mulai dataran rendah hingga dataran tinggi. (MacKinnon et al, 2010), menuliskan walet linchi (Collocalia linchi) sebagai jenis walet yang paling umum disemua ketinggian, selalu beraktivitas dalam kelompok, termasuk burung pemakan serangga kecil dan mencari makan dengan cara menyambar. Walaupun walet linchi (Collocalia linchi) termasuk burung dengan status konservasi beresiko rendah namun populasinya menurun (BirdLife International 2016; IUCN Red List 2016)

Status konservasi untuk setiap spesies burung yang ditemukan ada yang dilindungi dan ada juga yang tidak dilindungi. Berdasarkan Peraturan Menteri Lingkungan Hidup dan Kehutanan Republik Indonesia No. P.106/Menlhk/Setjen/Kum.1/12/2018, terdapat 8 spesies burung yang dilindungi yaitu daralaut tengkuk-hitam (Sterna sumatrana), daralaut sayap-putih (Chlidonias leucopterus), daralaut tiram (Gelochelidon nilotica), elanglaut perut putih (Haliaeetus leucogaste), elang brontok (Spizaetus cirrhatus), kipasan belang (Rhipidura javanica), camar sabine (Xema sabini), dan cikalang besar (Fregata minor).

Status konservasi jenis burung dalam International Union for Conservation of Nature (IUCN) Red List yang dijumpai di Hutan Mangrove Pulau Kelagian Besar tergolong dalam kategori Least Concern (berisiko rendah). Burung-burung yang ditemukan umumnya terbang secara individu dan berkelompok, melintas atau singgah di hutan mangrove Pulau Kelagian Besar. Terdapat 2 spesies burung yang masuk dalam daftar Appendix II Convention on International Trade in Endangered Species (CITES) di hutan Mangrove Pulau Kelagian Besar, yaitu elang laut perut putih (Haliaeetus leucogaste) dan elang brontok (Spizaetus cirrhatus). Elang laut perut putih (Haliaeetus leucogaste) dan elang brontok (Spizaetus cirrhatus) merupakan predator dalam rantai makanan yang berperan penting sebagai keseimbangan ekosistem (Loindong et al., 2016; Safanah et al., 2018). Jenis-jenis burung yang ditemukan di Hutan Mangrove Pulau Kelagian Besar yang masuk ke dalam kategori Appendix Convention on International Trade in Endangered Species (CITES) hanya dari famili Accipitridae. Walaupun demikian, menurut Nainggolan et al. (2019), jenis burung yang belum termasuk kedalam status kategori Appendix Convention on International Trade in Endangered Species (CITES) perlu juga mendapat perlindungan dalam rangka mencegah terjadinya penurunan jumlah burung tersebut. Hal yang sama diungkapkan oleh Ridki et al. (2016) bahwa burung merupakan suatu bagian dari keanekaragaman hayati yang perlu dijaga kelestariannya dari kepunahan.

Spesies burung yang dijumpai pada saat pengamatan yaitu sedang bertengger, bermain, dan makan di pohon. Burung merupakan satwaliar yang mempunyai mobilitas tinggi dan memiliki kemampuan hidup hampir di semua tipe habitat yang luas (Rohiyan et al., 2014). Sifat dinamis yang dimiliki burung mampu menjadi indikator perubahan lingkungan suatu wilayah (Adelina et al., 2016) dan membantu regenerasi hutan secara alami (Kamaluddin et al., 2019). Kondisi hutan yang stabil mampu memberikan ruang yang nyaman bagi burung-burung dalam melakukan aktivitas dan menemukan sumber pakan karena keanekaragaman dipengaruhi oleh beberapa faktor habitat seperti: melimpahnya efipit, buah-buahan, keterbukaan lantai dan juga komposisi pohon (Nasrudin et al., 2015). Habitat alami dapat mempengaruhi keberadaan burung terkecuali burung yang telah beradaptasi dengan lingkungan manusia. 


\section{KESIMPULAN DAN SARAN}

Hasil penelitian mencatat 27 spesies burung dari 21 famili dengan total individu sebanyak 741 ekor ditemukan di Hutan Mangrove Pulau Kelagian Besar. Nilai indeks keanekaragamannya yaitu 2.26, termasuk sedang. Artinya, kondisi ekosistem hutan mangrove di pulau tersebut relatif stabil untuk mendukung kehidupan burung liar. Terdapat 8 spesies burung yang dilindungi yaitu daralaut tengkuk-hitam (Sterna sumatrana), daralaut sayap-putih (Chlidonias leucopterus), daralaut tiram (Gelochelidon nilotica), elanglaut perut putih (Haliaeetus leucogaste), elang brontok (Spizaetus cirrhatus), kipasan belang (Rhipidura javanica), camar sabine (Xema sabini), dan cikalang besar (Fregata minor). Berdasarkan hasil pengamatan di lapangan, maka diusulkan saran agar adanya penelitian lanjutan mengenai hubungan biota laut dengan jenis burung serta perilaku keseharian burung saat di Hutan Mangrove Pulau Kelagian Besar.

\section{DAFTAR PUSTAKA}

Abdullah. 2013. Keberadaan Burung dan Penggunaan Habitat di Kawasan Pantai Kecamatan Syiah Kualakota Banda Aceh. Jurnal Jesbio, 3(2): 2302-1705.

Adelina, M., Harianto, S. P. dan Nurcahyani, N. 2016. Keanekaragaman Jenis Burung di Hutan Rakyat Pekon Kelungu Kecamatan Kota Agung Kabupaten Tanggamus. Jurnal Sylva Lestari, 2(4): 51-60.

Ekowati, A., Setiyani, A. D., Haribowo, D. R., Hidayah, K. 2016. Keanekaragaman Jenis Burung di Kawasan Telaga Warna, Desa Tugu Utara, Cisarua, Bogor. Journal of Biology, 9(2): 87-94.

Fikriyanti, M., Wulandari, S., Fauzi, I., Rahmat, A. 2018. Keragaman Jenis Burung Pada Berbagai Komunitas di Pulau Sangiang, Provinsi Banten. Jurnal Biodjati, 3(2): 157-165.

Firdaus, A. B., Setiawan, A., Rustiati, E. L. 2014. Keanekaragaman Spesies Burung di Repong Damar Pekon Pahmungan Kecamatan Pesisir Tengah Krui Kabupaten Lampung Barat. Jurnal Sylva Lestari, 2(2): 1-6.

Ghafur, A., Labiro, E., Ihsan, M. 2016. Asosiasi Jenis Burung Pada Kawasan Hutan Mangrove di Anjungan Kota Palu. Warta Rimba, 4(1): 42-48.

Heru, S. 2013. Status Ekologi Hutan Mangrove Pada Berbagai Tingkat Ketebalan. Jurnal Penelitian Kehutanan Wallacea, 2(2): 104-120.

IUCN. 2020. The IUCN Red List of Threatened Species. Version 2020-1.

Jhenkhar, M., Jadeyegowda, M., Khusalappa, CG., Ramesh, MN. dan Satish B.N. 2016. Bird Diversity Across Different Vegetation Types in Kodagu, Central Westrn Ghats, India. International Journal of Zoology and Research (IJZR), 6(3): 25-36.

Julyanto., Harianto, S. P., Nurcahyani, N. 2016. Studi Populasi Burung Famili Ardeidae di Rawa Pacing Desa Kibang Pacing Kecamatan Menggala Timur Kabupaten Tulang Bawang Provinsi Lampung. Jurnal Sylva Lestari, 4(2): 109-116.

Kamaluddin, A., Winarno, G.D., Dewi, B.S. dan Harianto, S.P. Keanekaragaman Jenis Burung untuk Mendukung Kegiatan Ekowisata Birdwatching di Pusat Latihan Gajah Taman Nasional Way Kambas. Jurnal Hutan Tropis, 7(3): 283-292.

Kristianti, M., Elhayat. Dan Ihsan, M. 2017. Pola Penyebaran Jenis Burung di Kawasan Hutan Desa Namo Kecamatan Kulawi Kabupaten Sigi. Warta Rimba, $5(1): 1-5$.

Latupapua, L. 2016. Jenis dan Habitat Burung Paruh Bengkok pada Hutan Wae Illie Taman Nasional Manusela. Jurnal IImu Budidaya Tanaman, 5(2): 67-77.

Lekipiou, P. dan Nanlohy, L.H. 2018. Kelimpahan dan Keanekaragaman Jenis Burung di Hutan Mangrove Kampung Yenanas Kabupaten Raja Ampat. Jurnal IImu-IImu Eksakta, 10(2): 12-19. 
Loindong, A., Kiroh, H., Wahyuni, I. dan Saerang, J.L.P. 2016. Tingkah Laku Makan Elang Laut Perut Putih (Haliaeetus leucogaste) di Pusat Penyelamatan Satwa Tasik Oki Sulawesi Utara. Jurnal Zootek, 36(1): 147-157.

MacKinnon, et al. 2010; dalam Iswandaru, D., Khalil, A. R. A., Kurniawan, B., Pramana, R., Febryano, I. G., Winarno, G. D. 2018. Kelimpahan dan Keanekaragaman Jenis Burung di Hutan Mangrove Kphl Gunung Balak. Indonesian Journal of Conservation, (1): 57-62.

MacKinnon J, Philipps K, dan van Balen B. 2010. Seri Panduan Lapangan BurungBurung di Sumatera, Jawa, Bali, dan Kalimantan. Bogor: LIPI.

Magurran AE. 2004. Measuring Biological Diversity. Malden. Blackwell Publishing.

Majid, I., Al Muhdar, M. H. I., Rohman, F., Syamsuri, I. 2016. Konservasi Hutan Mangrove di Pesisir Pantai Kota Ternate Terintegrasi dengan Kurikulum Sekolah. Jurnal Bioedukasi, 4(2): 488-496.

Mardiyanti, D. E., Wicaksono, K. P., Baskara, M. 2013. Dinamika Keanekaragaman Spesies Tumbuhan Pasca Pertanaman Padi. Jurnal Produksi Tanaman, 1(1): 2435.

Mubarrok, M.M. dan Ambarwati, R. 2019. Keanekaragaman Burung di Kawasan Hutan Mangrove Banyuurip Kecamatan Ujungpangkah Kabupaten Gresik. Jurnal Riset Biologi dan Aplikasinya, 1(2): 54-63.

Nasrudin, M., Nitibaskara, T. U. dan Rusli, A. R. 2015. Keanekaragaman Jenis Burung di Taman Wisata Alam Gunung Pancar Provinsi Jawa Barat. Jurnal Nusa Sylva, 15(2): 8-17.

Paramita, E.C., Kuntjoro, S. dan Ambarwati, R. 2015. Keanekaragaman dan Kelimpahan Jenis Burung di Kawasan Mangrove Center Tuban. LenteraBio, 4(3): 161-167.

Patang. 2012. Analisis Strategi Pengelolaan Hutan Mangrove (Kasus di Desa TongkeTongke Kabupaten Sinjai). Jurnal Agrisistem, 8(2): 100-109.

Ridki, M., Ulfira., Sari, S.L. dan Kamal, S. 2016. Keanekaragaman Burung di Kawasan Pesisir Rinon Pulo Breuh Kabupaten Aceh Besar. Prosiding Seminar Nasional Biotik, 3(1): 167-172.

Rohiyan, M., Setiawan, A., Rustiati, E. L. 2014. Keanekaragaman Jenis Burung di Hutan Pinus dan Hutan Campuran Muarasipongi Kabupaten Mandailing Natal Sumatera Utara. Jurnal Sylva Lestari, 2(2): 89-98.

Safanah, N.G., Partasasmita, R. dan Rakhman, Z. 2018. Aktivitas Harian Elang Brontok (Nisaetus cirrhatus) di Pusat Konservasi Elang Kamojang. Jurnal Metamorfosa, 5(1): 57-63.

Sajria., Toknok, B., Rukmini. 2019. Keanekaragaman Jenis Tumbuhan Obat Pada Kawasan Hutan Produksi Desa Malonas Kecamatan Dampelas Kabupaten Donggala. Jurnal Warta Rimba, 7(1): 17-22.

Sari, R.N., Safe'i,R. dan Iswandaru, D. 2019. Biodiversitas Fauna Sebagai Salah Satu Indikator Kesehatan Hutan Mangrove. Jurnal Perennial, 15(2): 62-66.

Setia, T. M. 2008. Penyebaran Biji oleh Satwa Liar di Kawasan Pusat Pendidikan Konservasi Alam Bodogol dan Pusat Riset Bodogol, Taman Nasional Gunung Gede Pangrango, Jawa Barat. Vis Vitalis, 1(1): 1-8.

Sukmantoro W., M. Irham, W. Novarino, F. Hasudungan, N. Kemp \& M. Muchtar. 2007. Daftar Burung Indonesia No. 2. Indonesian Ornithologists' Union. Bogor.

Supriyanto., Indriyanto., Bintoro, A. 2014. Inventarisasi Jenis Tumbuhan Obat di Hutan Mangrove Desa Margasari Kecamatan Labuhan Maringgai Lampung Timur. Jurnal Sylva Lestari, 2(1): 67-76.

Watalee, H., Ningsih, S., Ramlah, S. 2013. Keanekaragaman Jenis Burung di Hutan Rawa Saembawalati Desa Tomui Karya Kecamatan Mori Atas Kabupaten Morowali. Warta Rimba, 1(1): 1-8. 